\title{
Retraction Note: LncRNA TUG1 promoted KIAA1199 expression via miR-600 to accelerate cell metastasis and epithelial- mesenchymal transition in colorectal cancer
}

\author{
Junfeng Sun ${ }^{1 *}$, Jiyi Hu², Guojun Wang ${ }^{1}$, Zhen Yang ${ }^{1}$, Chunlin Zhao ${ }^{1}$, Xiefu Zhang ${ }^{1}$ and Jiaxiang Wang ${ }^{3}$
}

Retraction to: J Exp Clin Cancer Res 37, 106 (2018)

https://doi.org/10.1186/s13046-018-0771-x

The Editor-in-Chief has retracted this article [1] because after publication it was found that the authors did not obtain ethics approval prior to commencing the study. Additionally, concerns were raised regarding a number of image duplications within Figs. 2d, e, 4g and $\mathrm{f}$.

All authors agree to this retraction.

\section{Author details}

${ }^{1}$ Department of Gastrointestinal Surgery, The First Affiliated Hospital of Zhengzhou University, No.1 Jianshe East, Zhengzhou 450052, China.

${ }^{2}$ Colorectal Cancer Center, Fudan University, Shanghai, China. ${ }^{3}$ Pediatric Surgery, The First Affiliated Hospital of Zhengzhou University, Zhengzhou, China.

Published online: 04 February 2021

\section{Reference}

1. Sun J, Hu J, Wang G, et al. LncRNA TUG1 promoted KIAA1199 expression via miR-600 to accelerate cell metastasis and epithelial-mesenchymal transition in colorectal cancer. J Exp Clin Cancer Res. 2018;37:106. https:// doi.org/10.1186/s13046-018-0771-x.

The original article can be found online at https://doi.org/10.1186/s13046018-0771-x

* Correspondence: sunjunfenger@126.com

'Department of Gastrointestinal Surgery, The First Affiliated Hospital of Zhengzhou University, No.1 Jianshe East, Zhengzhou 450052, China

Full list of author information is available at the end of the article

C C The Author(s). 2021 Open Access This article is licensed under a Creative Commons Attribution 4.0 International License, which permits use, sharing, adaptation, distribution and reproduction in any medium or format, as long as you give appropriate credit to the original author(s) and the source, provide a link to the Creative Commons licence, and indicate if changes were made. The images or other third party material in this article are included in the article's Creative Commons licence, unless indicated otherwise in a credit line to the material. If material is not included in the article's Creative Commons licence and your intended use is not permitted by statutory regulation or exceeds the permitted use, you will need to obtain permission directly from the copyright holder. To view a copy of this licence, visit http://creativecommons.org/licenses/by/4.0/ The Creative Commons Public Domain Dedication waiver (http://creativecommons.org/publicdomain/zero/1.0/) applies to the data made available in this article, unless otherwise stated in a credit line to the data. 